\title{
Implication of drainage basin parameters of a tropical river basin of South India
}

\author{
K. J. Babu $\cdot$ S. Sreekumar $\cdot$ Arish Aslam
}

Received: 5 September 2013/Accepted: 10 June 2014/Published online: 8 July 2014

(C) The Author(s) 2014. This article is published with open access at Springerlink.com

\begin{abstract}
Drainage morphometry provides quantitative description of the drainage system which is an important aspect of the characterisation of watersheds. Chalakudi River is one of the important rivers of the South India which has attracted attention of many environmental scientists recently because of the proposed Athirapally Hydel Project across the river. SRTM (Shuttle Radar Topographic Mission) data were used for preparing DEM (Digital Elevation Model), Aspect Map and Slope Map. Geographical Information System (GIS) was used for the evaluation of linear, areal and relief aspects of morphometric parameters. The study reveals that the terrain exhibits dentritic and trellis pattern of drainage. The Chalakudi River Basin has a total area of $1,448.73 \mathrm{~km}^{2}$ and is designated as seventhorder basin. The drainage density of the basin is estimated as 2.54 and the lower-order streams mostly dominate the basin. The high basin relief indicates high runoff and sediment transport. The elongation ratio of the Chalakudi Basin is estimated as 0.48 and indicates that the shape of the basin is elongated. The development of stream segments in the basin area is more or less effected by rainfall. Relief ratio indicates that the discharge capability of watershed is very high and the groundwater potential is meagre. The low value of drainage density in spite of mountainous relief indicates that the area is covered by dense vegetation and resistant rocks permeated by fractures
\end{abstract}

\section{K. J. Babu}

Research and Post Graduate Department of Chemistry, Christ College, Irinjalakuda 680125, India

\section{S. Sreekumar $(\bowtie) \cdot$ A. Aslam}

Research and Post Graduate Department of Geology and Environmental Science, Christ College, Irinjalakuda 680125, India

e-mail: sreeavani1961@gmail.com and joints. These studies are helpful in watershed development planning and wise utilization of natural resources.

Keywords GIS · Morphometric analysis · Geology · Chalakudi River Basin

\section{Introduction}

Morphometric analysis of a watershed provides a quantitative description of the drainage system which is an important aspect of the characterisation of watersheds (Strahler 1964). Many workers (Horton 1945; Miller 1953; Nag 1998) have recognised inter relationship between drainage network architecture and parameters such as climate, geology, relief and structural features in the basin. Recently many authors have attempted to generate more precise data on morphometric parameters using satellite data and GIS tools (Manu and Anirudhan 2008; Magesh et al. 2013; Sreedevi et al. 2005; Ozdemir and Bird 2009; Mesa 2006). Using SRTM data and GIS technique morphometric analysis can be carried out speedily and with great precision (Grohmann 2004; Smith and Sandwell 2003). Chalakudy River is the fourth longest river in Kerala and enjoys humid tropical climate. This study is very relevant at this period of time as a group of Environmental scientists has raised concern over the proposed Athirapally Hydro Electric Project across the Chalakudi River. Due to erratic rainfall pattern and uncontrolled sand mining, groundwater levels have declined to deeper levels. Agriculture is the main occupation of the people in the area. Therefore, watershed development schemes become very relevant in the present contest. To prepare a comprehensive watershed development plan, it becomes necessary to understand the topography, erosion status and drainage pattern of the region. The objective of the present study is to 


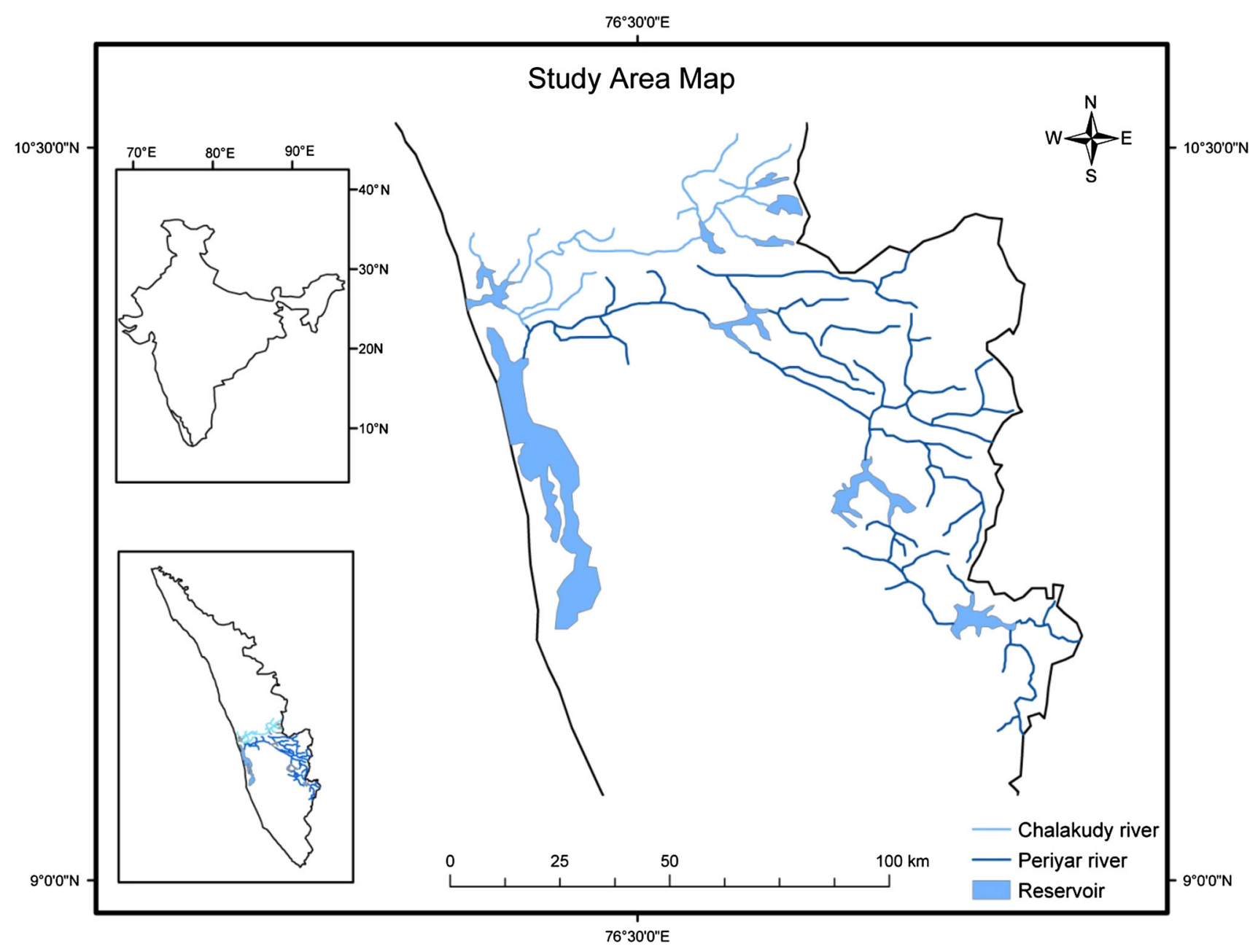

Fig. 1 Chalakudi River Basin

find out the relationship between the morphometric parameters and hydrological parameters.

\section{Study area}

Chalakudy River Basin (CRB) lies between $10^{\circ} 15^{\prime}-10^{\circ} 35^{\prime}$ North latitude and $76^{\circ} 15^{\prime}-76^{\circ} 55^{\prime}$ East longitude (Fig. 1). This area is located in Thrissur, Ernakulam and Palakkad districts of Kerala which lies in the South West coast of Indian Peninsula. The Chalakudy river basin with an area of $1,448.73 \mathrm{~km}^{2}$ is the tributaries of the Periyar, the largest river in Kerala. Out of the total catchment, about $300 \mathrm{~km}^{2}$ lies in Tamil Nadu state. The river originates from the Anamalai hills of the Western Ghats and drains through the highland, midland and lowland areas of the state. It merges with the river Periyar at Elanthikara, before debouching into the Vembanad Lake. The river is formed by the confluence of five major tributaries, viz. Parambikulam, Sholayar, Kuriarkutti, Karappara and Anakkayam tributaries. Parambikulam and Sholayar tributaries originate from the Tamil Nadu and other three from Kerala. These tributaries confluence at place called Orukombankuthy just $8 \mathrm{~km}$ East to the Peringalkuthu and flows westward as Chalakudy river making many rapids and pools including the famous Vazhachal and Athirapally waterfalls. A unique characteristic of this river basin is that at least $1,200 \mathrm{~km}^{2}$ catchment area of Kerala is under the control of the forest department. The total annual yield of the river basin is estimated as $1,922.99 \mathrm{~mm}^{3}$ (CWRDM 1995-Water Atlas of Kerala). The important reservoirs within the river basin are Perivaripallam reservoir, Thunakadavu reservoir, Parambikulam reservoir, Sholayar reservoir and Peringalkuthu reservoir.

\section{Geology}

Geologically the CRB is covered mainly by the Archean Crystallines. Sedimentary formation ranging in age from 


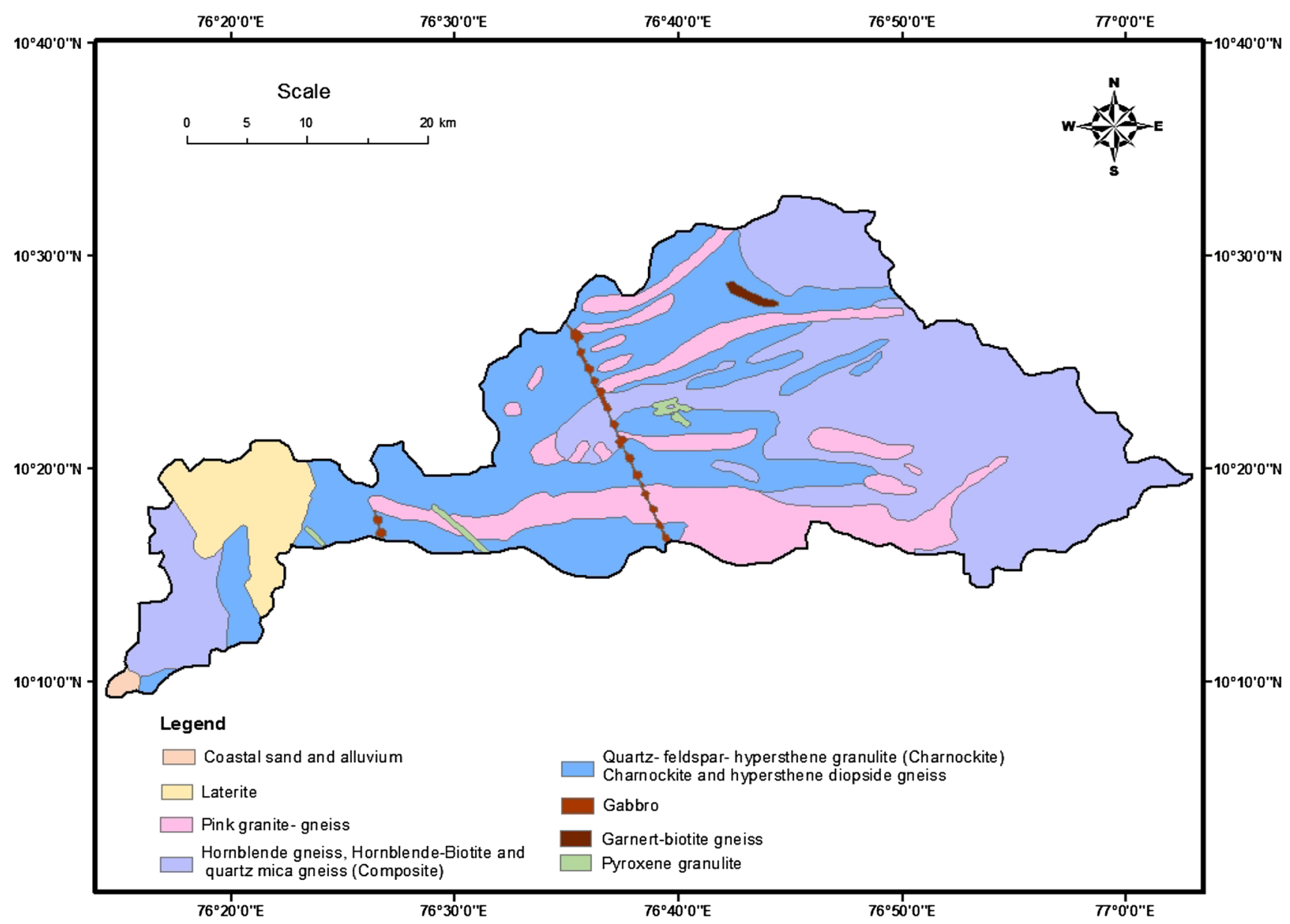

Fig. 2 Geology of the Chalakudi River Basin

Recent to Sub Recent are found overlain the crystallines rocks along the coast (Soman 2002). The crystallines are composed mainly of Charnockite, Charnockite gneiss, Hornblende gneiss and Hornblende biotite and Quartz gneiss. The Archeans are intruded by Granites and Gabbro rocks at many places. Intrusive bodies of Pyroxene granulite are also seen at some places. Widespread lateritisation is common over the crystalline. The recent to sub recent formations includes coastal sands and alluvium. The geology of the area is given in the Fig. 2. Eastern and Northern part of CRB is dominantly occupied by Hornblende gneiss, Quartz mica gneiss and Charnockite. Pink granitic gneiss, Pyroxene granulite and Hornblende gneiss dominate the central part of the basin.

\section{Geomorphology and climate}

Geomorphologically the basin is characterised by flood plain, transitional plain, low rolling terrain, moderately undulating terrain, highly undulating terrain and hilly area. The average annual rainfall in the area is $3,300 \mathrm{~mm}$, varying from $2,900 \mathrm{~mm}$ in the downstream side to $3,700 \mathrm{~mm}$ in the uphill side. A high degree of slope is noticed in the Eastern and Northern part of the basin, mostly occupied by Hornblende gneiss and Quartz mica gneiss. Central part of the basin which is occupied by Pink granitic gneiss, Pyroxene granulite, Hornblende gneiss is characterised by gentler slope. Seasonal variation of temperature is within $5{ }^{\circ} \mathrm{C}$. Temperature rises during March, with a maximum of $33.45^{\circ} \mathrm{C}$.

\section{Methodology}

The morphometric analysis of CRB was prepared based on Survey of India published topographic maps 1:50,000 scale and also on SRTM data. The drainage pattern was initially derived from the toposheets and later updated using linearly stretched False Colour Composite (FCC) of IRS-1C LISS 3 satellite data. Some of the first-order drainage was updated from satellite data. The drainage pattern for the delineated five subwatersheds was exported to the Arc-Info GIS Software for morphometric analysis. The measurement 
Table 1 Linear, relief and areal parameters

\begin{tabular}{|c|c|c|c|c|}
\hline $\begin{array}{l}\text { Sl. } \\
\text { no }\end{array}$ & $\begin{array}{l}\text { Morphometric } \\
\text { parameters }\end{array}$ & $\begin{array}{l}\text { Short } \\
\text { form }\end{array}$ & Formula & References \\
\hline 1 & Area $\left(\mathrm{km}^{2}\right)$ & A & & \\
\hline 2 & Perimeter (km) & $\mathrm{P}$ & & \\
\hline 3 & Stream order & $\mathrm{U}$ & & Strahler (1964) \\
\hline 4 & $\begin{array}{r}\text { Number of } \\
\text { segments }\end{array}$ & $\mathrm{Nu}$ & & \\
\hline 5 & $\begin{array}{l}\text { Stream length } \\
(\mathrm{m} \text { or } \mathrm{km})\end{array}$ & $\mathrm{Lu}$ & & Horton (1945) \\
\hline 6 & $\begin{array}{l}\text { Mean stream } \\
\text { length }\end{array}$ & Lsm & $\mathrm{Lsm}=\mathrm{Lu} / \mathrm{Nu}$ & \\
\hline 7 & $\begin{array}{l}\text { Stream length } \\
\text { ratio }\end{array}$ & RL & $\begin{array}{c}\mathrm{RL}=\mathrm{Lu} / \\
\mathrm{Lu}-1\end{array}$ & $\begin{array}{l}\text { Sreedevi et al. } \\
\text { (2005) }\end{array}$ \\
\hline 8 & Bifurcation ratio & $\mathrm{Rb}$ & $\begin{array}{c}\mathrm{Rb}=\mathrm{Nu} / \\
\mathrm{Nu}+1\end{array}$ & Horton (1932) \\
\hline 9 & $\begin{array}{l}\text { Mean bifurcation } \\
\text { ratio }\end{array}$ & $\mathrm{Rbm}$ & Average of $\mathrm{Rb}$ & \\
\hline 10 & Basin relief & $\mathrm{Bh}$ & $\mathrm{Bh}=\mathrm{H}-\mathrm{h}$ & \\
\hline 11 & Relief ratio & $\mathrm{Rh}$ & $\mathrm{Rh}=\mathrm{Bh} / \mathrm{Lb}$ & $\begin{array}{c}\text { Schumm } \\
\text { (1963) }\end{array}$ \\
\hline 12 & $\begin{array}{l}\text { Ruggedness } \\
\text { number }\end{array}$ & $\mathrm{Rn}$ & $\mathrm{Rn}=\mathrm{Bh} \times \mathrm{Dd}$ & \\
\hline 13 & Drainage density & Dd & $\mathrm{Dd}=\mathrm{SLu} / \mathrm{A}$ & Horton (1945) \\
\hline 14 & $\begin{array}{l}\text { Stream } \\
\text { frequency }\end{array}$ & Fs & $\mathrm{Fs}=\mathrm{Nu} / \mathrm{A}$ & Horton (1945) \\
\hline 15 & Drainage texture & $\mathrm{T}$ & $\mathrm{T}=\mathrm{Dd} \times \mathrm{Fs}$ & Smith (1950) \\
\hline 16 & Form factor & $\mathrm{Rf}$ & $\mathrm{Rf}=\mathrm{A} / \mathrm{Lb}^{2}$ & Horton (1945) \\
\hline 17 & Circulatory ratio & $\mathrm{Rc}$ & $\mathrm{Rc}=4 \mathrm{pA} / \mathrm{P}^{2}$ & Strahler (1964) \\
\hline 18 & Elongation ratio & $\operatorname{Re}$ & $\begin{array}{l}\mathrm{Re}=1.128 \times \\
\text { ÖA/Lb }\end{array}$ & Schumn (1956) \\
\hline
\end{tabular}

of basic parameters of the drainage basin viz., length, area, number of streams and perimeter of the sub basins is done with the software. From the basic parameters, other parameters like bifurcation ratio, stream length ratio, stream frequency, drainage density were estimated. Drainage texture, basin relief, relief ratio, elongation ratio, circulatory index and form factor were evaluated with the help of established mathematical equations (Table 1). The morphometric characters were divided into three categories linear, areal and relief aspects of the basin.

\section{Results and discussions}

The total drainage area of the CRB is $1,448.73 \mathrm{~km}^{2}$ and is divided into five sub-basins for the analysis (Fig. 3; Table 2). The development of drainage networks depends on geology, rainfall and intensity of erosion. In the present study only sixth-order sub-basins are analysed for the morphometry. The area, basin length of each basin and number of segments are presented in Table 2. Sub-basin 1 is having the maximum area and sub-basin 5 with minimum area.

\section{Linear aspects}

Linear aspects such as stream order, stream number for various orders, bifurcation ratio, stream length for various stream orders and length ratio were determined and results have been presented in Tables 2, 3, 4, 5 and 6.

Stream number $(\mathrm{Nu})$

The order-wise total number of stream segments is known as stream number. The data reveal that the number of stream segments gradually decreases as the stream order increases (Table 2). The decrease in the number of stream segments is experienced because when a channel of low order joins a channel of higher order, the channel downstreams retain the higher of two orders (Chow Ven et al. 1988).

\section{Stream order $(\mathrm{U})$}

Stream order gives an idea of its size and approximate index of stream flow. The Chalakudi River is a seventhorder basin. Ranking of streams has been carried out based on the methods proposed by Strahler (1957). Subbasins 1,2 and 3 were identified under sixth order and sub-basins 4 and 5 are under fifth order. First- and secondorder streams were dominating all these sub-basins (Table 2). The number of first-order streams indicates the mature stage of topography (Dhruv Sen Singh and Amit Awasthi 2011).

\section{Stream length $(\mathrm{Lu})$}

The stream length ( $\mathrm{Lu}$ ) has been computed based on the law proposed by Horton (1945) for the subwatersheds. The stream lengths for all sub-basins of various orders have been measured from digitised map with the help of Map Maker gratis of GIS. The maximum length of total watersheds is $3,261.68$ and that of five sub-basins are $652.94,727.13,588.99,300.89$ and 193.77 , respectively (Table 3). In general, the total length of stream segment is the maximum in first-order streams and decreases with an increase in the stream order. This observation is consistent with that of Magesh et al. (2013) and Chitra et al. (2011). The length of a given order is more than that of next lower order which indicates that the basin evolution follows the erosion loss acting on geologic material with homogenous weathering and erosion characteristics (Nag and Chakraborty 2003). 


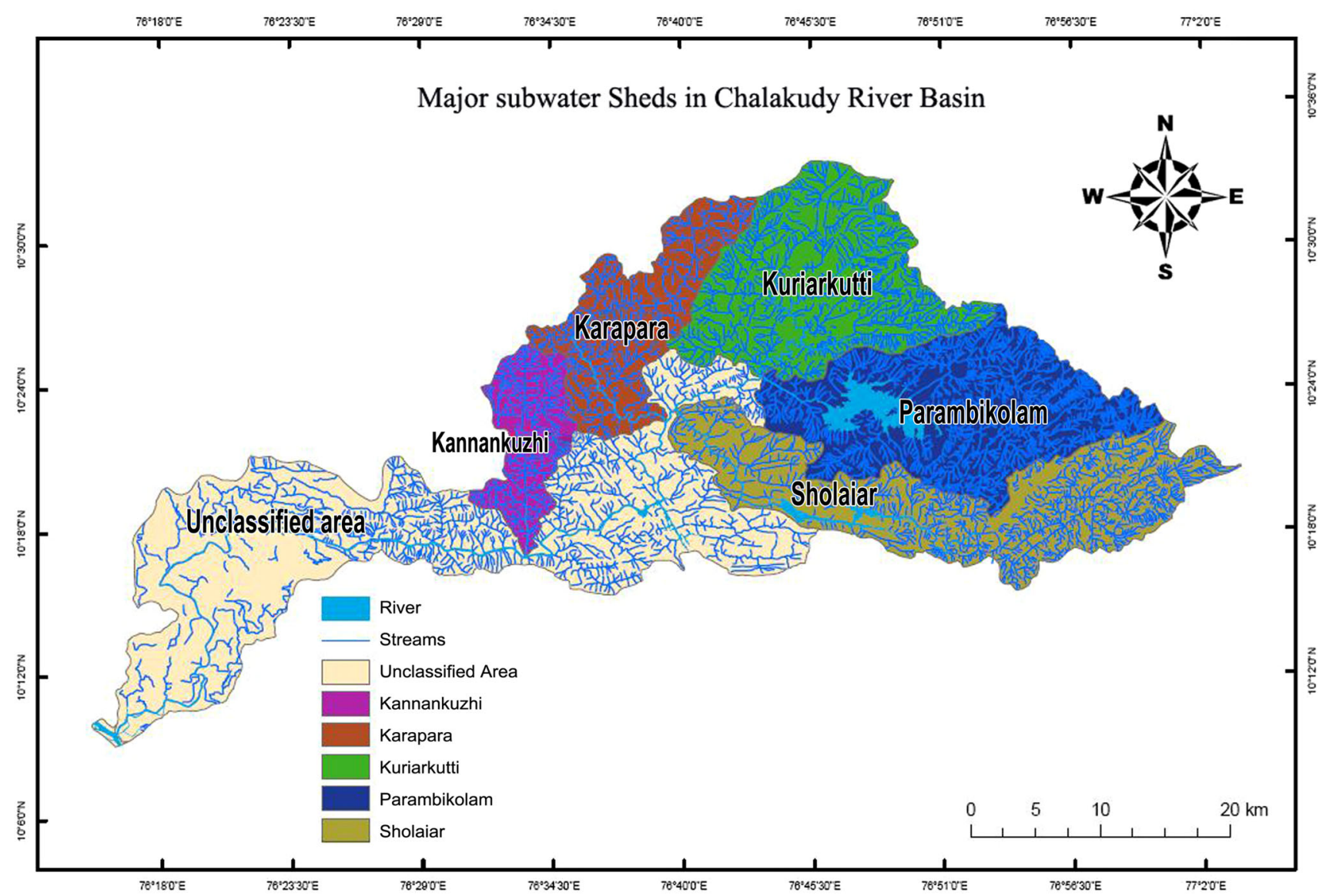

Fig. 3 Major subwatersheds in Chalakudi River Basin

Table 2 Area, basin length and number of segments of CRB and subwatersheds (SW)

\begin{tabular}{|c|c|c|c|c|c|c|c|c|c|c|}
\hline \multirow[t]{2}{*}{ SW name } & \multirow{2}{*}{$\begin{array}{l}\text { Area } \\
\left(\mathrm{km}^{2}\right)\end{array}$} & \multirow{2}{*}{$\begin{array}{l}\text { Basin } \\
\text { length } \\
(\mathrm{km})\end{array}$} & \multicolumn{8}{|c|}{ Number of segments $(\mathrm{Nu})$} \\
\hline & & & 1 & 2 & 3 & 4 & 5 & 6 & 7 & Total \\
\hline Sub-basin 1 & 254.65 & 49.86 & 710 & 210 & 52 & 13 & 5 & 1 & - & 991 \\
\hline Sub-basin 2 & 252.86 & 35.61 & 848 & 210 & 70 & 27 & 2 & 1 & - & 1,158 \\
\hline Sub-basin 3 & 232.31 & 27.05 & 558 & 232 & 86 & 48 & 2 & 1 & - & 927 \\
\hline Sub-basin 4 & 132.09 & 31.26 & 299 & 132 & 55 & 4 & 1 & - & - & 491 \\
\hline Sub-basin 5 & 71.92 & 16.89 & 209 & 99 & 48 & 3 & 1 & - & - & 360 \\
\hline CRB & $1,448.73$ & 89.88 & 3,361 & 1,245 & 441 & 209 & 34 & 3 & 1 & 5,294 \\
\hline
\end{tabular}

Stream length ratio $(\mathrm{Rl})$

Stream length has an important relationship with the surface flow and discharge. The total length of all streams in the basin is calculated to be 2.76 . The values vary from 0.25 to 1.70 for sub-basins, while it ranges from 0.29 to 1.57 for the whole basin (Tables 4, 5). The stream length ratio between successive stream orders varies due to differences in slope and topographic conditions (Sreedevi et al. 2005).
Bifurcation ratio $(\mathrm{Rb})$

The ratio of number of segments of a given order $(\mathrm{Nu})$ to the number of segment of higher order $(\mathrm{Nu}+1)$ is termed as bifurcation ratio (Strahler 1964). According to Mesa (2006) bifurcation ratio is a measure of the degree of ramification of the drainage network. The values usually range between 3.00 and 5.00 for network formed in homogeneous rocks (undergone minimum structural 
Table 3 Stream length of CRB and subwatersheds

\begin{tabular}{|c|c|c|c|c|c|c|c|c|}
\hline \multirow[t]{2}{*}{ SW name } & \multicolumn{8}{|c|}{ Stream length $(\mathrm{km}), \mathrm{Lu}$} \\
\hline & 1 & 2 & 3 & 4 & 5 & 6 & 7 & Total \\
\hline Sub-basin 1 & 400.01 & 117.64 & 53.01 & 31.09 & 43.24 & 7.95 & - & 652.94 \\
\hline Sub-basin 2 & 475.93 & 120.61 & 58.37 & 33.46 & 18.70 & 20.07 & - & 727.14 \\
\hline Sub-basin 3 & 357.86 & 108.26 & 47.64 & 46.92 & 14.21 & 14.11 & - & 589 \\
\hline Sub-basin 4 & 185.75 & 57.08 & 20.79 & 21.11 & 16.16 & - & - & 300.89 \\
\hline Sub-basin 5 & 124.69 & 35.84 & 13.78 & 7.19 & 12.27 & - & - & 193.77 \\
\hline CRB & $2,069.81$ & 613.11 & 253.37 & 169.19 & 104.58 & 20.07 & 31.55 & $3,261.68$ \\
\hline
\end{tabular}

Table 4 Mean stream length of CRB and subwatersheds

\begin{tabular}{llllllllll}
\hline SW name & \multicolumn{7}{l}{ Mean stream length (Lsm) } \\
\cline { 2 - 10 } & 1 & 2 & 3 & 4 & 5 & 6 & 7 & Total \\
\hline Sub-basin 1 & 0.56 & 0.56 & 1.02 & 2.39 & 8.65 & 7.95 & - & 21.13 \\
Sub-basin 2 & 0.56 & 0.57 & 0.83 & 1.24 & 9.35 & 20.07 & - & 32.62 \\
Sub-basin 3 & 0.64 & 0.47 & 0.55 & 0.98 & 7.10 & 14.11 & - & 23.85 \\
Sub-basin 4 & 0.62 & 0.43 & 0.38 & 5.28 & 16.16 & - & - & 22.87 \\
Sub-basin 5 & 0.60 & 0.36 & 0.29 & 2.40 & 12.27 & - & - & 15.92 \\
CRB & 0.62 & 0.49 & 0.57 & 0.81 & 3.08 & 6.69 & 31.55 & 43.81 \\
\hline
\end{tabular}

Table 5 Stream length ratio of the CRB and subwatersheds

\begin{tabular}{llllllll}
\hline SW name & \multicolumn{7}{l}{ Stream length ratio (RL) } \\
\cline { 2 - 8 } & $2 / 1$ & $3 / 2$ & $4 / 3$ & $5 / 4$ & $6 / 5$ & $6 / 7$ & Total \\
\hline Sub-basin 1 & 0.29 & 0.45 & 0.59 & 1.39 & 0.18 & - & 2.9 \\
Sub-basin 2 & 0.25 & 0.48 & 0.57 & 0.56 & 1.07 & - & 2.93 \\
Sub-basin 3 & 0.30 & 0.44 & 0.99 & 0.30 & 0.99 & - & 3.02 \\
Sub-basin 4 & 0.31 & 0.36 & 1.02 & 0.77 & - & - & 2.46 \\
Sub-basin 5 & 0.29 & 0.38 & 0.52 & 1.71 & - & - & 2.9 \\
CRB & 0.30 & 0.41 & 0.67 & 0.62 & 0.19 & 1.57 & 3.76 \\
\hline
\end{tabular}

Table 6 Bifurcation ratio and mean bifurcation ratio of the CRB and sub watersheds

\begin{tabular}{llllllll}
\hline SW name & \multicolumn{7}{l}{ Bifurcation ratio $(\mathrm{Rb})$} \\
\cline { 2 - 8 } & $1 / 2$ & \multicolumn{1}{l}{$2 / 3$} & \multicolumn{1}{c}{$3 / 4$} & \multicolumn{1}{l}{$4 / 5$} & $5 / 6$ & $7 / 6$ & Mean Rb \\
\hline Sub-basin 1 & 3.38 & 4.04 & 4.00 & 2.60 & 5.00 & - & 3.17 \\
Sub-basin 2 & 4.04 & 3.00 & 2.59 & 13.50 & 2.00 & - & 5.03 \\
Sub-basin 3 & 2.41 & 2.70 & 1.79 & 24.00 & 2.00 & - & 6.58 \\
Sub-basin 4 & 2.27 & 2.40 & 13.75 & 4.00 & - & - & 4.48 \\
Sub-basin 5 & 2.11 & 2.06 & 16.00 & 3.00 & - & - & 5.79 \\
CRB & 2.70 & 2.82 & 2.11 & 6.15 & 11.33 & 3 & 4.69 \\
\hline
\end{tabular}

disturbances) and value with more than 10 shows the influence of structures (Chow Ven et al. 1988).

In the study area, the mean $\mathrm{Rb}$ varies from 3.17 to 6.58 and the mean $\mathrm{Rb}$ of entire basin is 4.69. The lower value of
$\mathrm{Rb}$ indicates the absence of structural control. The higher $\mathrm{Rb}$ value for the sub-basin 3 (6.58) and sub-basin 5 (5.79) indicates a mature topography (Table 6).

Areal aspects

The area of the basin was computed by converting the map of the basin into a polygon form.

Drainage density (Dd)

A strong relationship exists between various environmental variables and Dd (Sreedevi et al. 2009). Tucker and Brass (1998), established a positive correlation between Dd and rainfall parameters. Gardiner (1995) showed that the greater Dd generally associated with impermeable rocks. Dd is inversely related to hydraulic conductivity of underlying soil. The Dd for the whole basin is $2.51 \mathrm{~km} / \mathrm{km}^{2}$ while those of the five sub-basins are shown in Table 7 . Low Dd occurs in the region of highly resistant and permeable subsoil materials with dense vegetative cover and low relief.

\section{Drainage texture $(\mathrm{T})$}

Drainage texture $(\mathrm{T})$ depends upon a number of natural factors such as climate rainfall vegetation, rock and soil type, infiltration capacity, relief and evolutionary stage of the basin (Kale and Gupta 2001). The high values of the drainage texture for the basin (9.16) indicate intermediate texture (Smith 1950). The value indicates (Table 7) that the channels are close to each other. Sub-basins 2, 3 and 5 are classified under fine category and sub-basins 1 and 4 under intermediate.

Stream frequency (Fs)

The stream frequency of CRB is 3.65 (Table 7), which means that three streams are developed in an area of $1 \mathrm{~km}^{2}$ in the basin. A higher stream frequency points to larger surface runoff and steeper ground surface (Vittala et al. 2004). 
Table 7 Areal parameters of CRB and subwatersheds

\begin{tabular}{lllllll}
\hline SW name & $\begin{array}{l}\text { Drainage density } \\
(\mathrm{Dd})\end{array}$ & $\begin{array}{l}\text { Drainage texture } \\
(\mathrm{T})\end{array}$ & $\begin{array}{l}\text { Stream frequency } \\
(\mathrm{Fs})\end{array}$ & $\begin{array}{l}\text { Elongation ratio } \\
(\mathrm{Re})\end{array}$ & $\begin{array}{l}\text { Circulatory ratio } \\
(\mathrm{Rc})\end{array}$ & $\begin{array}{l}\text { Form factor } \\
(\mathrm{Rf})\end{array}$ \\
\hline Sub-basin 1 & 2.56 & 9.96 & 3.89 & 0.36 & 0.21 & 0.10 \\
Sub-basin 2 & 2.88 & 13.19 & 4.58 & 0.50 & 0.37 & 0.20 \\
Sub-basin 3 & 2.54 & 10.13 & 3.99 & 0.64 & 0.47 & 0.39 \\
Sub-basin 4 & 2.28 & 8.48 & 3.72 & 0.41 & 0.39 & 0.14 \\
Sub-basin 5 & 2.69 & 13.48 & 5.01 & 0.57 & 0.02 & 0.25 \\
CRB & 2.51 & 9.16 & 3.65 & 0.48 & 0.18 \\
\hline
\end{tabular}

Form factor (Rf)

It is defined as the ratio of the basin area $(A)$ to the square value of the basin length ( $\mathrm{Lb}$ ). The form factor varies from 0 (in highly elongated shape) to the unity, i.e. 1 (in perfect circular shape). Hence higher the value of form factor more circular the shape of the basin and vice versa. Form factor of the river basin is 0.18 , which denotes a highly elongated form. While the Rf of five sub-basins are shown in Table 7.

\section{Elongation ratio $(\mathrm{Re})$}

According to Schumn (1956) elongation ratio is the ratio of the diameter of a circle $(D)$ of the same area in the basin to the maximum basin length (Lb). The elongation ratio of the Chalakudi River Basin is estimated as 0.48 , which shows that the basin is elongated. Sub-basins 2 and 5 are characterised by relatively high Re value compared to that of sub-basins 1, 3 and 4 (Table 7). The sub-basins with low Re value are susceptible to high erosion and sediment yield. It indicates relief and steep slope (Singh and Singh 1997). High values of elongation ratio indicated that the denudational process plays a major role in controlling the shape of the basin (Manu and Anirudhan 2008).

Circularity ratio $(\mathrm{Rc})$

The Circularity ratio $(\mathrm{Rc})$ is expressed as the ratio of the area of the basin $(A)$ to the area of a circle having the same perimeter as that of the basin (Strahler 1964). Rc values approaching 1 indicates that the basin shapes are circular. The Rc value for CRB is estimated as 0.02 (Table 7), while those for other sub-basins range from 0.21 to 0.47 . The low value indicates that it is elongated and not structurally controlled.

\section{Relief aspects}

Evaluation of the relief aspects such as ruggedness number $(\mathrm{Rn})$, relief ratio $(\mathrm{Rh})$ and basin relief is derived from the dataset.
Table 8 Relief parameters CRB and sub watersheds

\begin{tabular}{llll}
\hline SW name & Basin relief $(\mathrm{Bh})$ & Relief ratio & $\begin{array}{l}\text { Ruggedness } \\
\text { number (Rn) }\end{array}$ \\
\hline Sub-basin 1 & 1888 & 0.04 & 4.84 \\
Sub-basin 2 & 1284 & 0.04 & 3.691 \\
Sub-basin 3 & 1091 & 0.04 & 2.765 \\
Sub-basin 4 & 1003 & 0.03 & 2.283 \\
Sub-basin 5 & 1004 & 0.06 & 2.704 \\
CRB & 2326 & 0.03 & 5.847 \\
\hline
\end{tabular}

Basin relief (Bh)

Basin relief is the difference in elevation between the highest and lowest point of the basin. It determines the slope and so the runoff and sediment transport. The basin relief is determined as 2,326 $\mathrm{m}$, indicating high runoff and sediment transport (Table 8).

Relief ratio $(\mathrm{Rh})$

When the basin relief $(H)$ is divided by maximum basin length (Lb) gives the relief ratio (Schumm 1954). It measures the overall steepness of the drainage basin and is an indicator of the intensity of erosion processes. The relief ratio of the river basin is 0.03 (Table 8 ). The subbasin 5 is having relatively high relief ratio (0.06) compared to the other subwatersheds (Table 6).

\section{Ruggedness number $(\mathrm{Rn})$}

Ruggedness number $(\mathrm{Rn})$ is the product of basin relief $(H)$ and drainage density $(\mathrm{Dd})$. The $\mathrm{Rn}$ of the entire Chalakudi River Basin is 5,838 (Table 8), indicating a very high basin relief. All the sub-basins have high value of Rn indicating high relief. Such high values are characteristic of mountainous region of tropical climate with high rainfall (Schumn 1956). 
Impact of sand mining and proposed hydroelectric project

One of the main human interventions happening in the river basin is the unscientific and ruthless sand mining practices in the downstream segment of the Chalakudi River. Dredging of sand from the river bed has lowered the river bed even below the sea level in many places and altered the river flow and water quality downstream (Babu et al. 2007). Although the Kerala river bank protection and regulations of sand mining act (2001) exists, the violation is observed in many instances. Only by changing the mindset of the powerful mining lobbies the degradation of the river can be prevented.

Another threat to the riverine ecosystem is from the proposed Athirappilly hydroelectric project. The new 23-m high dam proposed upstream of the famous Athirappilly and Vazhachal waterfalls and downstream of the already existing six dams which would bring about the destruction of around $1.44 \mathrm{~km}^{2}$ of tropical riparian forest and will seriously affect the flow and beauty of the two waterfalls. Moreover, new project proposal as a peak load station will severely alter the operation of major irrigation projects and hundreds of lift irrigation schemes and drinking water schemes in the downstream site. The conflict arising out of the new project in the context of overall water utilization in the river basin, impact on the existing project and water consumers including agriculturists is to be avoided.

\section{Conclusions}

Based on the drainage order the CRB has been classified as seventh-order basin. Eastern and Northern part of CRB is dominantly occupied by Hornblende gneiss, Quartz mica gneiss and Charnockite and is characterised by high degree of slope. Central part of the basin which is occupied by Pink granitic gneiss, Pyroxene granulite and Hornblende gneiss shows gentler slope. The Dd of Chalakudy drainage basin, as well as those of the five sub basins, reveals that the sub surface strata are highly resistant and permeable. This is a characteristic feature of coarse drainage as the density values are $<5.0$. The study reveals that the drainage area of the basin is passing through an early mature stage of the fluvial geomorphic cycle. Lower-order streams mostly dominate the basin. The development of stream segments in the basin area is more or less affected by rain fall. High values of elongation ratio indicated that the denudational process plays an important role in controlling the shape of the basin. The mean $\mathrm{Rb}$ value (4.69) indicates that the drainage pattern is not much influenced by geological structures. The low values of bifurcation ratios and very low value of drainage densities indicate that the drainage has not been affected by structural disturbances and also that the area is covered under dense vegetation cover. Relief ratio indicates that the discharge capability of the watersheds is very high and ground water potential is meagre. These studies are very useful for rainwater harvesting and watershed management plans. First- and second-order streams are not useful for constructing check dams in the study area because the streams are situated on high elevated area with steep slope. The state of Kerala is densely populated and the unscientific landuse practices in the drainage basin enhance the runoff rate and hinder the rate of infiltration. This causes lowering of water table level particularly during extreme summer seasons. This is posing a threat to water security in the region and the state in general. At this context more check dams and water conservation practices are very relevant in a state like Kerala. This study is helpful in the identification and location of check dams in a more appropriate place. However, the proposed dam across the Chalakudi River for generating electricity is not advisable. Unscientific sand mining must be restricted to day time and prohibited during peak monsoon months. Violations of rules and regulations pertaining to river sand mining must be dealt with meticulously and severe punishment be imposed to the offenders. Mindset of the people must changed by proper awareness programme.

Acknowledgments The authors wish to thank Department of Environment and Climate Change, Government of Kerala for financial assistance.

Open Access This article is distributed under the terms of the Creative Commons Attribution License which permits any use, distribution, and reproduction in any medium, provided the original author(s) and the source are credited.

\section{References}

Babu KN, Padmalal D, Maya K, Sreeja R, Arun PR (2007) Quality of surface and groundwater around tile and brick clay mines in the Chalakudi River Basin, South Western India. J Geol Soc India 69:279-284

Chitra C, Alaguraja P, Ganeshkumari K, Yuvaraj D, Manivel M (2011) Watershed characteristics of Kundah subbasin using remotesensing and GIS techniques. Int $\mathrm{J}$ Geomat Geosci 2(1):311-335

Chow Ven T, David RM, Larry WM (1988) Handbook of applied hydrology. McGraw Hill Inc., New York

CWRDM (1995) Water Atlas of Kerala. Centre for Water Resource Development and Management, Kozhikode

Gardiner V (1995) Channel networks: progress in the study of spatial and temporal variations of drainage density. In: Gornell A, Petts GE (eds) Change in river channels. Wiley, New York, pp 65-85

Grohmann CH (2004) Morphometric analysis in geographical information systems: application of free software GRASS and R. Comput Geosci 30:1055-1067 
Horton RE (1932) Drainage basin characteristics. Trans Amer Geophys Union 13:350-361

Horton RE (1945) Erosional development of streams and their drainage basin. Hydrophysical approach to quantitative morphology. Geol Soc Am Bull 55(3):275-370

Kale VS, Gupta A (2001) Introduction to geomorphology. Orient Longman Limited, New Delhi, pp 82-101

Magesh NS, Jitheshlal KV, Chandrasekar N, Jini KV (2013) Geographical information system based morphometric analysis of Bharathapuzha River Basin, Kerala, India. Appl Water Sci 3:467-477

Manu MS, Anirudhan S (2008) Drainage cahercteristics of Achankovil River Basin, kerala. J Geol Soc India 71:841-850

Mesa LM (2006) Morphometric analysis of a subtropical Andean basin (Tucumam, Argentina). Environ Geol 50(8):1235-1242

Miller VC (1953) A quantitative geomorphic study of drainage basin characteristics in the clinch mountain area. Virginia and Tennessee. In: Technical Report. 3. Office of Naval Research. Department of Geology. Columbia University

Nag SK (1998) Morphometric analysis using remote sensing techniques in the Chaka sub basin, Purulia District, West Bengal. J Indian Soc Remote Sens 26(1\&2):69-76

Nag SK, Chakraborty S (2003) Influence of rock types and structures in the development of drainage network in the hard rock area. J Indian Soc Remote Sens 31(1):25-35

Ozdemir H, Bird Deanne (2009) Evaluation of morphometric parameters of the drainage network derived from topographic map DEM in point of floods. Environ Geol 56:1405-1415

Schumm SA (1954) The relation of drainage basin relief to sediment loss. In: Tenth General Assembly Rome, Pub. International Association of Hydrology, IUGG, vol 1. pp 216-219

Schumm SA (1963) Sinuosity of alluvial river on the great plains. Bull Geol Soc Amer 74:1089-1100
Schumn SA (1956) Evolution of drainage system and slopes in badlands at Perth Amboy, New Jersey. Geol Soc Am Bull 67:597-646

Singh DS, Awasthi A (2011) Implication of drainage basin parameters of Chhoti, Gandak River, Ganga plain, India. J Geol Soc India 78:370-378

Singh S, Singh MC (1997) Morphometric analysis of Kanhar River Basin. Natl Geogr J India 43(1):31-43

Smith KG (1950) Standards for grading texture of erosional topography. Am J Sci 248:655-668

Smith B, Sandwell D (2003) Accuracy and resolution of Shuttle Radar Topographic Mission data. Geophys Res Lett 30(9):20-21

Soman K (2002) Geology of Kerala. Geological Society of India, Bangalore, p 335

Sreedevi PD, Subrahmanyam K, Shakeel A (2005) The significance of morphometric analysis for obtaining groundwater potential zones in a structurally controlled terrain. Environ Geol 47(3):412-420

Sreedevi PD, Owais S, Khan HH, Ahamed S (2009) Morphometric analysis of a watershed of South India using SRTM data and GIS. Jour Geol Soc India 73:543-552

Strahler AN (1957) Quantitative analysis of watershed Geomorphology. Trans Am Geophys Union 38:913-920

Strahler AN (1964) Quantitative geomorphology of drainage basin and channel network. In: Chow VT (ed) Handbook of applied hydrology. McGraw Hill Book Company, New York

Tucker GE, Brass RL (1998) Hill slope processes, drainage density and landscape morphology. Water Resour Res 34:2751-2764

Vittala SR, Govindaiah S, Gowda HH (2004) Morphometric analysis of sub watersheds in the Pavagada area of Tumkur District, South India using remote sensing and GIS technique. J Indian Soc Remote Sens 32:351-362 